\section{Research Expenditure on Fisheries}

THE report of the committee of inquiry into the fishing industry, of which Lord Fleck was chairman, laid emphasis on adequate finance being available for scientific and industrial research bearing on the industry. In moving the second reading of the White Fish and Herring Industries Bill in the House of Commons on January 31, the Minister of Agricul ture, Fisheries and Food, Mr. C. Soames, said that the Bill was not prompted by the Fleck report, to implement which would require major legislation and detailed consultation before such legislation could be drafted; and the importance of research for the fishing industry was stressed. Mr. J. H. Hey sug. gested that if the normal fishing grounds were con. tracted, research directed towards the discovery of new fishing grounds should be undertaken; and Capt. M. Hewiton inquired specifically whether the possibility of fishing grounds off the coast of Ghana had been investigated. He thought the prospects of industrial fishing in that area were unlimited. Sir William Duthie also strongly urged adequate research to remove as much guesswork as possible from fishing, particularly as regards the incidence of shoal migra. tion, and suggested that in this way we could find the answer to the depletion of the herring shoals in the North Sea. Other speakers agreed that, as the Fleck Committee pointed out, the fishing industry in many aspects lags behind other industries in the adoption of modern equipment, methods and organiza. tion; but it is also recognized that the question of research is closely linked with the economic aspects, since the application of its results inereasingly involved large capital expenditure, beyond the resources of the small owner.

Mr. H. Hughes, who quoted the estimated figure of $£ 1$ million for expenditure by Britain on fisheries research in $1959-60$, with a further $£ 250,000$ for research into handling and processing fish, referred also to the view of the Fleck Cormmittee that a much more intensive research effort could profitably be directed towards exploiting more effectively the resources of the sea, and that to keep pace with changing conditions, the industry should devote a substantially greater sum to the development of improved catching and processing techniques. Questions raised in the debate relating to the closing of one of the three research stations at Aberdeen led the Secretary of State for Scotland, Mr. J. S. Maclay, to be at some pains to explain that the station which had been sold to Unilever, Ltd., which would continue research there, was the Ministry of Agriculture, Fisheries and Food Experimental Food Station, which was not primarily a fishing research station. The Marine Life Laboratory of the Department of Agriculture and Fisheries for Scotland, adjacent to the Department of Scientific and Industrial Research's research station at Torry, are both continuing and cover research into fish and the sea, biology, hydrography and the abundance and distribution of commercial fish stocks.

\section{Telephone Services in Britain}

Is opening a debate in the House of Lords on February 11 on the Post Office Telephone Service, prompted by the White Paper (Cmnd. 973) on Post Office Capital Expenditure, 1960-61, Lord Crook said that there are at least six main reasons why a steady figure for capital investment is essential for the telephone service. One of these is a steady research programme, and this is closely related both to the telecommunications industry and to the growth of electronics in the world of the telephone, where, Lord Crook believes, Britain is in danger of losing a great market. He questioned whether the Dollis Hill Experimental Establishment has been allowed to get ahead fast enough and given sufficient opportunity and finance. It is important, ho said, to realize that the telephone service earns monoy, internally in industry within Britain, and also in respect of exports. The Earl of Listowel, supporting much that Lord Crook had said, added that the telephone service in Britain is backward because we have not put sufficient capital into the manufacture of tele. phone equipment and have not ensured for the Post Office the normal programme of capital development that any large business enterprise requires.

Replying for the Government on the debate, Lord St. Oswald assured the House that no limitation has been placed on research for electronic exchanges because of shortage of capital investment. It has been deliberately decided to employ different techniques in different functional sections of the experimental exchange at Highgate Wood, so that their merits can be compared from all points of view; the ultimate aim is an economic standard electronic exchange. Lord St. Oswald claimed that work is proceeding at high pressure to produce improved designs, so that British industry can retain its position in the forefront of telecommunication development and be able to offer in world markets electronic exchanges fully competitive with those of any other manufacturers. He pointed out, however, that development is not solely for export, and a besetting problem generally is the comparative lack of enthusiasm among telephone subscribers for anything new. The average residential telephone user makes less than one call a day on his instrument, and even putting business and residential subscribers together, the average is only 530 a year, compared with between 1,000 and 2,000 in Sweden, Canada and the United States. The Post Office, in conjunction with the University of London, has recently instituted a joint research programme into the sociology of telephone usage.

\section{Research on Mental Health in Britain}

The Minister of Health, Mr. E. Powell, in a written answer in the House of Commons on Fobruary 8, stated that after completing its full-scale review of mental health research oarly in 1959 , the Medical Research Council established a now committee on clinical psychiatry, under Sir George Pickering as chairman, and one on the epidemiology of mental disorders, with Sir Aubrey Lewis as chairman. Each committce has appointed working parties to study special aspects of its field, such as the psychopathic personality, the value of drugs in psychiatry as assessed by clinical trials, and the use of national statistics of mental disorders. Of the total funds available to the Council for the past five years, the percentage spent on mental health research was as follows : $1956-57,2 \cdot 3 ; 1957-58,1 \cdot 8 ; 1958-59,3 \cdot 8$; $1959-60,4 \cdot 4 ; 1960-61,4 \cdot 7$.

\section{Rostherne Mere, Cheshire, as a Nature Reserve}

Rostherne Mere and some surrounding woodland in north Cheshire have been presented to the Nature 